\title{
ÉVELYNE BLOCH-DANO, Honoré de Balzac
}

\section{Marco Stupazzoni}

\section{(2) OpenEdition \\ Journals}

\section{Edizione digitale}

URL: https://journals.openedition.org/studifrancesi/45239

DOI: 10.4000/studifrancesi.45239

ISSN: 2421-5856

\section{Editore}

Rosenberg \& Sellier

\section{Edizione cartacea}

Data di pubblicazione: 1 août 2021

Paginazione: 385

ISSN: 0039-2944

\section{Notizia bibliografica digitale}

Marco Stupazzoni, «Évelyne bloch-dano, Honoré de Balzac», Studi Francesi [Online], 194 (LXV | II) | 2021, online dal 01 septembre 2021, consultato il 15 octobre 2022. URL: http://journals.openedition.org/ studifrancesi/45239; DOI: https://doi.org/10.4000/studifrancesi.45239

Questo documento è stato generato automaticamente il 15 octobre 2022.

\section{(c) (i) ()}

Creative Commons - Attribuzione - Non commerciale - Non opere derivate 4.0 Internazionale - CC BYNC-ND 4.0

https://creativecommons.org/licenses/by-nc-nd/4.0/ 


\title{
ÉVELYNE BLOCH-DANO, Honoré de Balzac
}

\author{
Marco Stupazzoni
}

\section{NOTIZIA}

ÉVELYNE BLOCH-DANO, Honoré de Balzac, in Le case dei miei scrittori, traduzione di S. Prencipe e M. Volante, Torino, add editore, 2019, pp. 23-27.

1 Ogni casa di scrittore racchiude in sé una parte di immaginario che consente allo sguardo interiore del visitatore di intraprendere un percorso di ricerca volto a percepire l'intero universo simbolico dell'autore, che prende corpo in un'atmosfera materiale che si incarna, a volte, anche in semplici oggetti. Luoghi simbolici di memoria (divenuti, in qualche caso, museo), le diverse dimore balzachiane formano un itinerario che, guidato dallo sguardo interiore del visitatore, porta a collegare una casa all'universo letterario, oltre che vitale, dello scrittore.

2 A partire da un racconto, La Grenadière, che può essere letto "come un crogiolo in cui sono stati fusi gli elementi della vicenda biografica di Balzac» (p. 23), passando per la dimora di Saché il cui «paesaggio femminile, tutto curve, acque dolci, pascoli floridi» (p. 24) è descritto nel Lys dans la vallée, si arriva alla residenza di rue Raynouard. È qui che bisogna cercare lo scrittore: il «contrasto fra l'esiguità delle cose e l'immensità dell'opera è immenso. [...] Lo scarto fra la modestia del contesto e il lavoro titanico dell'autore ci ricorda che se lui lavorava dando le spalle alla finestra non è soltanto perché scriveva di notte ma perché il mondo che stendeva sulla carta prorompeva dalla camera oscura al suo cervello» (p. 27). 